\title{
Antenatal diagnosis of Niemann-Pick disease in a twin pregnancy
}

\author{
P DONNAI*, D DONNAI $\dagger$, R HARRIS $\dagger$, R STEPHENS,+ E YOUNG + , \\ AND S CAMPBELL § \\ From * the University Department of Obstetrics and Gynaecology, \\ and $\dagger$ the University Department of Medical Genetics, St Mary's Hospital, Manchester M13 OJH; \\ $\ddagger$ the Hospital for Sick Children, Great Ormond Street, London WCI; and \\ \$the University Department of Obstetrics and Gynaecology, King's College Hospital Medical School, \\ London SE5
}

SUMmary An Ashkenazi Jewish woman had a child with Niemann-Pick disease in her first marriage. She subsequently remarried a man who was also heterozygous for the condition and conceived twins. Prenatal diagnostic tests were performed and one twin was shown to be homozygous and the other heterozygous for Niemann-Pick disease. The problems of prenatal diagnosis and counselling in twin pregnancies are discussed.

Since 1971 it has been possible to diagnose NiemannPick disease antenatally by assay of sphingomyelinase in cultured amniotic fluid cells. ${ }^{1}$ We report a twin pregnancy where prenatal diagnosis showed that the twins were discordant for the disease.

\section{Case report}

The patient was a 31-year-old woman of Ashkenazi Jewish origin. In her first marriage to a non-consanguineous man of similar extraction she had a 6week miscarriage and two normal term deliveries. The first child had acute infantile Niemann-Pick disease and died at the age of $2 \frac{1}{2}$ years. The second child, a postmature boy weighing $2 \cdot 3 \mathrm{~kg}$, died at 2 days of meconium aspiration. In 1978, following her remarriage, again to an unrelated Ashkenazi Jewish man, the patient requested antenatal diagnosis for Niemann-Pick disease if her husband was found to be a heterozygote. Although the husband's leucocyte sphingomyelinase was within the lowest part of the normal range, the ratios of the levels of this enzyme to other lysosomal enzymes assayed in the same material were those of a heterozygote carrier of Niemann-Pick disease. The husband's mother was also found to have enzyme levels characteristic of a heterozygote (table 1). The patient booked for antenatal care 10 weeks from the first day of the last normal menstrual period. There was no family history of twins. The uterus was then larger

Received for publication 29 September 1980
TABLE 1 Enzymatic activities of leucocytes

\begin{tabular}{|c|c|c|}
\hline & \multirow{2}{*}{$\begin{array}{l}\text { Sphingomyelinase } \\
\text { (nmol/mg protein } / h \text { ) }\end{array}$} & $\alpha$-galactosidase \\
\hline & & Sphingomyelinase \\
\hline & Mean \pm SD & \\
\hline Normal controls & $2 \cdot 1 \pm 1 \cdot 0$ & $44 \pm 19$ \\
\hline $\begin{array}{l}\text { Obligate heterozygotes } \\
(\mathrm{n}=14)\end{array}$ & $0 \cdot 65 \pm 0 \cdot 2$ & $110 \pm 42$ \\
\hline Mother & 0.79 & 95 \\
\hline Father & $1 \cdot 2$ & 107 \\
\hline Paternal grandmother & $1 \cdot 1$ & 83 \\
\hline Twin 1 & $0 \cdot 62$ & 165 \\
\hline Twin 2 & 0 & - \\
\hline
\end{tabular}

than expected from her dates and an ultrasound scan showed twin gestational sacs. At 16 weeks' gestation by dates, amniocentesis was performed at King's College Hospital under ultrasound control. Twin 1 presented by the vertex on the left side of the uterus and twin 2 was a breech lying on the right side. The fetal biparietal diameters were consistent with the gestational age and the large placental site was on the anterior wall of the uterus. A total of $20 \mathrm{ml}$ of clear liquor was obtained from each sac by amniocentesis through the outer margin of the uterine fundus on each side.

\section{Methods and results}

Leucocytes were homogenised in $0.5 \%$ sodium cholate and the supernatant used in the enzyme assays. The whole cell homogenate in water was used for the amniotic cell assays. Sphingomyelinase activity was determined as described by Patrick 
et $a l^{2}$ using ${ }^{3} \mathrm{H}$-sphingomyelin as substrate. In addition, the amniotic cell assays contained $250 \mu \mathrm{g}$ sodium cholate. Up to $300 \mu \mathrm{g}$ supernatant protein was used in leucocyte assays which were incubated for 4 hours.

$\beta$-galactosidase assay mixture contained 3 to $6 \mu \mathrm{g}$ whole homogenate protein in $0.4 \%$ serum albumin in $0.4 \mathrm{mmol} / 1 \mathrm{NaCl}(50 \mu \mathrm{l})$ and $1 \mathrm{mmol} / 1 \quad 4-$ methylumbelliferyl- $\beta$-D-galactopyranoside in McIlvaine phosphate-citric acid buffer, $\mathrm{pH} 4 \cdot 1(150 \mu \mathrm{l})$. After 15 minutes' incubation at $37^{\circ} \mathrm{C}$ the reaction was stopped by the addition of $0.25 \mathrm{~mol} / 1$ glycine$\mathrm{NaOH}, \mathrm{pH} 10 \cdot 4(2 \cdot 3 \mathrm{ml})$, and the liberated 4-methylumbelliferone measured fluorimetrically. $\alpha$-galactosidase was measured in a mixture containing leucocyte supernatant $(10 \mu \mathrm{l})$ and $10 \mathrm{mmol} / \mathrm{l} 4-$ methylumbelliferyl- $\alpha$-D-galactopyranoside in 0.2 $\mathrm{mol} / \mathrm{l}$ acetate buffer, $\mathrm{pH} 5 \cdot 0(50 \mu \mathrm{l})$, in a final volume of $100 \mu \mathrm{l}$. After 20 minutes' incubation at $37^{\circ} \mathrm{C}$ the reaction was stopped by the addition of $0.25 \mathrm{~mol} / \mathrm{l}$ glycine- $\mathrm{NaOH}, \mathrm{pH} 10.4(2.4 \mathrm{ml})$, and the liberated 4-methylumbelliferone measured fluorimetrically. The results of chromosome analysis and biochemical studies on the amniotic cell samples are shown in table 2. Twin 1, a female, was considered to be a heterozygote and twin 2 , a male, a homozygote for Niemann-Pick disease.

\section{Clinical course}

These results were explained to the couple at 19 weeks' gestation and because one twin was unaffected they elected to continue the pregnancy which progressed normally until the 36th week when spontaneous labour started. Intrapartum monitoring of the fetal heart rates showed a suboptimal pattern for the unaffected fetus on the left side of the uterus and caesarian section was performed at St Mary's Hospital, Manchester.

The first twin, a female, birthweight $2.06 \mathrm{~kg}$, presented by the breech and the second twin, a male, birthweight $2 \cdot 2 \mathrm{~kg}$, presented by the vertex. At delivery the condition of both infants was good and no resuscitation was necessary. The mother's postoperative course was uneventful.

TWIN 1 (FEMALE)

Physical examination after birth was normal. She became mildly jaundiced on the second day of life, phototherapy was commenced, and she was tubefed with expressed breast milk. By 7 days the jaundice had disappeared, she had regained her birthweight, and was then fully breast fed. Sphingomyelinase activity was assayed in white cells from cord blood collected at delivery and in venous blood taken on the second day. The results are shown in
TABLE 2 Enzymatic activities of cultured amniotic fluid cells

\begin{tabular}{llll}
\hline & Twin 1 & Twin 2 & $\begin{array}{l}\text { Normal } \\
\text { controls } \\
\text { (mean } \pm S D)\end{array}$ \\
\hline $\begin{array}{l}\text { Chromosomes } \\
\begin{array}{l}\text { Sphingomyelinase } \\
\text { nmol/mg protein/h }\end{array}\end{array}$ & $\begin{array}{l}\text { (1) } 21 \\
\text { (2) } 27\end{array}$ & $\begin{array}{l}\text { (1) } 0 \cdot 14 \\
\text { (2) } 0\end{array}$ & $\begin{array}{l}103 \pm 45 \\
(\mathrm{n}=17)\end{array}$ \\
$\begin{array}{l}\text { B-galactosidase } \\
\text { nmol/mg protein/h }\end{array}$ & (1) 498 & (1) 454 & $629 \pm 297$ \\
\hline
\end{tabular}

(1) Activity in cells cultured at the Institute of Child Health, London (2) Activity in cells cultured at Guy's Hospital, London

table 1 and they confirmed the antenatal diagnosis of heterozygote status for Niemann-Pick disease. Her development has been normal and now at the age of one year she is a healthy child who weighs $9 \cdot 5 \mathrm{~kg}$ and is beginning to walk.

TWIN 2 (MALE)

He was nursed in another lying-in ward since his parents had decided before his birth that they did not wish to see him and he should go into long term care. Physical examination revealed a liver enlarged $\vec{\bullet}$ $2 \mathrm{~cm}$ below the right costal margin. He became $\stackrel{\infty}{\rightarrow}$ jaundiced and required phototherapy. He was bottle fed on modified cow's milk. His jaundice disappeared by the age of 7 days and when he regained his birthweight at 10 days he was discharged into long term care. Sphingomyelinase activity in the white cells from cord blood and venous blood confirmed the antenatal diagnosis of Niemann-Pick disease. The results are shown in table 1 .

His subsequent progress has been typical of acute infantile Niemann-Pick disease. The spleen became palpable at 7 weeks and the liver increased in size. For the first 4 months he thrived and his development appeared to be normal. He was an alert baby, weighing $4.7 \mathrm{~kg}$ (at 4/12), and had good head control. There was, however, no further motor development and he never learned to sit up. Since 8 months there has been no further weight gain and he has had several episodes of vomiting and periods of pyrexia of no apparent cause. Now, at the age of one year he is a socially responsive, undernourished baby (weight $5 \cdot 25 \mathrm{~kg}$ ) with generalised hypotonia. His abdomen is large with a huge firm liver extending to the right groin and an enlarged spleen with notch extending into the left iliac fossa.

\section{Discussion}

Antenatal diagnosis of Niemann-Pick disease was first reported in 1971 by Epstein et $^{2}{ }^{1}$ at 13 weeks' gestation followed by therapeutic abortion of an affected fetus at 19 weeks' gestation. Amniocentesis in twin pregnancies is not without hazard, ${ }^{3}$ but using 
compound static B ultrasonic scan the membrane interface separating the twin sacs can be seen and amniotic fluid removed from both sacs. However, genetic counselling in such cases is complicated ${ }^{4}$ and in a similar situation in which one fetus of a twin pair was affected by Hurler's disease, Aberg et $a l^{5}$ performed cardiac puncture to kill the affected twin in utero at 24 weeks' gestation. Labour ensued at 33 weeks' gestation and the remnants of the dead fetus were delivered vaginally. The healthy twin was delivered successfully by caesarian section for transverse lie. ${ }^{5}$ Our patient was doubtful of her ability to cope practically and emotionally with another affected child but she did not wish to have an abortion since one twin was unaffected. The possibility of cardiac puncture of the affected twin was not discussed with her because of the possible risk of spontaneous abortion of the unaffected twin. The couple decided antenatally that the affected twin should go into long term hospital care and it was fortunate that the twins were of different sex so the unaffected twin could be placed with the parents immediately after delivery. Although the affected twin has remained in hospital, the parents have kept in regular contact and visited him.

Sympathetic counselling and long term support is vital for families faced with similar problems and serious consideration by patient and doctor needs to be given to possible outcomes before embarking on prenatal diagnosis in a twin pregnancy.

The enzyme assay of the cord blood was kindly performed by Dr A Cooper and Dr I B Sardharwalla of the Royal Manchester Children's Hospital. We are grateful to Miss Susan Blunt of the Paediatric Research Unit, Guy's Hospital for performing the chromosome analysis on the cultured amniotic fluid cells.

\section{References}

1 Epstein CJ, Brady RO, Schneider EL, Bradley RM, Shapiro D. In utero diagnosis of Niemann-Pick disease. Am J Hum Genet 1971 ;23:533-5.

2 Patrick AD, Young E, Kleijer WJ, Niermeijer MF. Prenatal diagnosis of Niemann-Pick disease type A using chromogenic substrate. Lancet 1977 ;ii:144.

3 Editorial. Genetic amniocentesis in twin pregnancies. Br Med J 1979 ;ii:1455-6.

4 Hunter AGW, Cox DM. Counselling problems when twins are discovered at genetic amniocentesis. Clin Genet $1979 ; 16: 34-42$.

5 Aberg A, Mitelman F, Cantz M, Gehler J. Cardiac puncture of fetus with Hurler's disease avoiding abortion of unaffected co-twin. Lancet 1978 ;ii:990-1.

Requests for reprints to Professor Rodney Harris, Department of Medical Genetics, St Mary's Hospital, Hathersage Road, Manchester M13 0JH.

\section{Note added in proof}

Twin 2 died in November 1980. 